\title{
Holocene Submarine Bayhead Delta Deposits: an example from the Southern Brazil
}

Ricardo P. Meireles, Laboratório de Oceanografia Costeira, Universidade Federal de Santa Catarina, Brazil.

Andrew J. G. Cooper, School of Environmental Sciences. University of Ulster. Coleraine, Northern Ireland.

Antonio H. F. Klein, Laboratório de Oceanografia Costeira, Universidade Federal de Santa Catarina, Brazil. José G. N. de Abreu, Laboratório de Oceanografia Geológica, Universidade do Vale do Itajaí, Brazil.

Andrew N. Green, School of Agriculture, Earth and Environmental Sciences, University of KwaZulu-Natal, South Africa.

Luis H. P. de Souza, Laboratório de Oceanografia Costeira, Universidade Federal de Santa Catarina, Brazil.

Elírio E. Toldo Jr., Instituto de Geociências, Universidade Federal do Rio Grande do Sul CECO/UFRGS, Brazil.

Copyright 2016, SBGf - Sociedade Brasileira de Geofísica

Este texto foi preparado para a apresentação no VII Simpósio Brasileiro de Geofísica, Ouro Preto, 25 a 27 de outubro de 2016. Seu conteúdo foi revisado pelo Comitê Técnico do VII SimBGf, mas não necessariamente representa a opinião da SBGf ou de seus associados. E proibida a reprodução total ou parcial deste material para propósitos comerciais sem prévia autorização da SBGf.

\section{Abstract}

Shallow geophysical investigations in the upper reaches of North Bay, Florianópolis reveal four seismic facies. These are interpreted as crystalline basement, Quaternary sediments, a bayhead delta and Holocene lagoon/embayment sediments, respectively. The $15 \mathrm{~m}$ thick Bayhead delta unit was deposited on top of a flooded, undulating land surface, suggesting rapid flooding during sea level rise. This created accommodation space for accumulation of bayhead delta sediments. The Bayhead delta unit contains abundant seaward-dipping foresets and small delta-to, channel-fill sequences. The upper surface is planar suggesting tidal ravinement during subsequent sea level rise to the late Holocene highstand. The upper surface is overlain by up to $10 \mathrm{~m}$ of fine-grained sediments typical of tranquil water deposition, but close to river mouths, a more proximal unit contains bedded gravel and sand, representing contemporary fluvial deposition. The present absence of bayhead delta sediments is attributed to lack of accommodation space.

\section{Introduction}

A bayhead delta forms at the head of a wave-sheltered environment such as an estuary, lagoon or a bay into which a river discharges (Penland \& Kulp, 2005). They form in variety of settings including prograding coasts, back-barrier lagoons, large embayments and are not restricted to incised valley systems (Bhattacharya \& Giosan, 2003).

In this paper the seismic stratigraphy of the upper reaches of Florianópolis North Bay, Santa Catarina, is described. Much of the sequence comprises a unit that is interpreted as a bayhead delta. The stratigraphy enables a preliminar interpretation of the evolution of the upper bay and its bayhead delta in the context of mid-late Holocene sea level changes. The interpretation is based on 10 line $\mathrm{km}$ of boomer seismics and two jet-probe cores (Figs 1 and 2). This mapping is part of an international geophysical/stratigraphy project investigating the development of the inner continental shelf.

Previous studies on the coastal plain and seismic interpretations in adjacents areas provide a chronological framework for interpretation of the depositional units (Hein et al., 2015; Cooper et al., submitted).

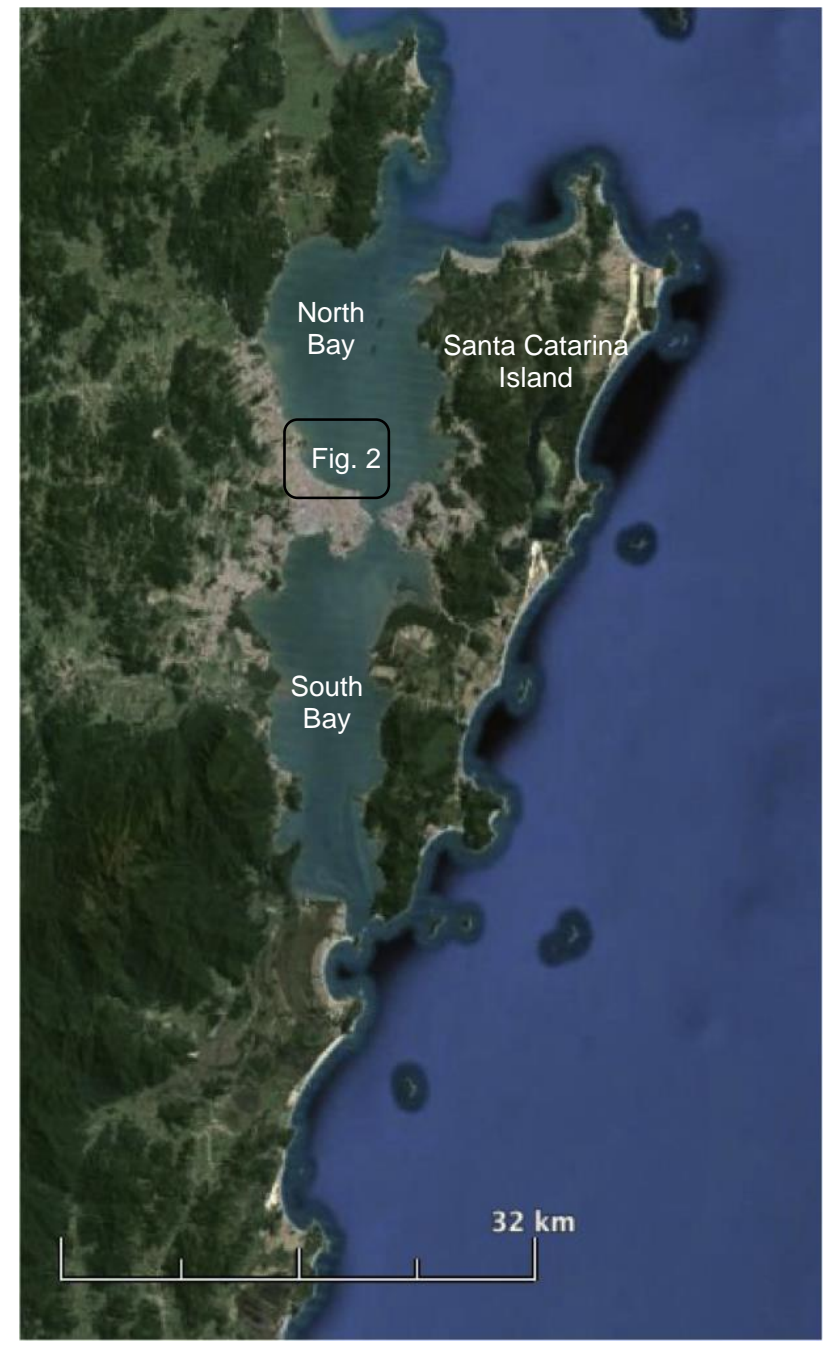

Figure 1 - Map of Santa Catarina Island, Brazil (lat S27.35 $-S 27.85^{\circ}$ and long. W48.35 $-W 48.85^{\circ}$ ). Black box is detail of seismic survey area with the position of cores (Fig. 2).

\section{Study Area}

The study area is located in southern Brazil, and is part of a large embayment system at Florianópolis North Bay (Fig. 2). On average, the depth of the bay is about 3.5 meters and the maximum depth is about 10 meters near the northern entrance of the bay (Bonetti et al., 1998). Recent sediments in the study area are dominated by silty-clay in the upper reaches and sand-silt which is limited to the mouth of the bay where energy levels are 
higher. The North Bay hydrodynamics and sedimentation processes are typical of closed bay environments (Campos, 2011).
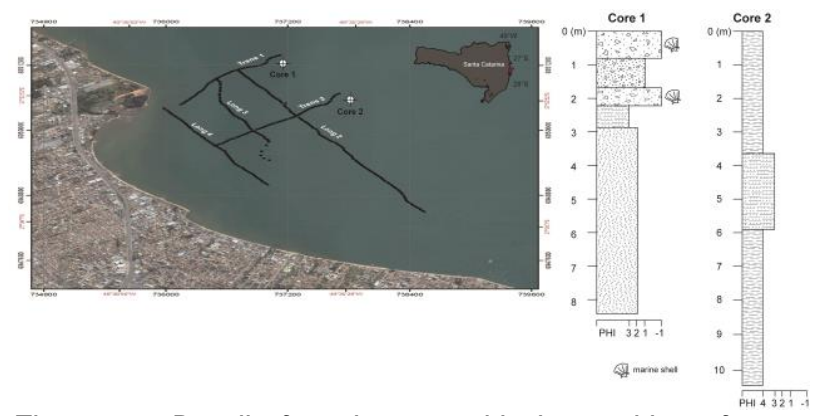

Figure 2 - Detail of study area with the position of cores and seismic data.

\section{Methods}

Ten line kilometers of seismic data were collected from the Florianopolis North Bay between depths of $\sim 2$ and $3.5 \mathrm{~m}$ depth (Fig. 2) using an RS232 EG\&GTM BOOMER system (200J-300J).

The acoustic source, mounted on a towed catamaran and a separate hydrophone array were towed behind the vessel. The data was recorded on a thermal graphics printer (EPC Labs. Inc. EPC 4.800 model). The paper records were digitized at 300Dpi for interpretation and annotation using Adobe Illustrator ${ }^{\circledR}$. Positioning was by a DGPS reference receiver Trimble $4000 \mathrm{RL}$ and differential receiver Trimble 4000 DL with a modem Kantronics All Mode to send corrections of the position every second with accuracy of \pm 0.1 to $0.5 \mathrm{~m}$. Two-way travel time was converted to depth assuming the speed of sound in water as $1500 \mathrm{~m} / \mathrm{s}$ for the entire water column and $1650 \mathrm{~m} / \mathrm{s}$ for bottom sediment.

Additionally, 6 jet-probe cores and CHIRP seismic lines (CHIRP type) from commercial investigations were used to provide context for the current study.

\section{Results and interpretation}

Five seismic units (1-5) separated by distinctive surfaces (1-4) were identified (Fig. 3). Each is described below.

Unit 1 represents the acoustic basement. It is a strong, high-amplitude reflector that is undulating with a surface relief of over $20 \mathrm{~m}$.

The high relief topography around the area is characterised by Proterozoic granite. This unit is interpreted to be the granite upper surface (Fig. 3).

Unit 2 is at least $15 \mathrm{~m}$ thick. It rests on the upper surface of unit 1. It is acoustically transparent and shows no discernible internal structure. It is laterally discontinuous and is only locally preserved on the margins of incised valleys. It is interpreted as a remnant Quaternary deposit preserved on interfluves as topographic highs (Fig. 3).

Unit 3 is at least $15 \mathrm{~m}$ thick. It was not fully penetrated in most locations. In some places it rests unconformably on unit 1 and unit 2. The lower surface of Unit 3 is a moderate amplitude reflector with highly variable topography. The unit comprises alternating high and low amplitude reflectors that drape or onlap the underlying units. Two orders of internal reflectors exist. The smallest order are seaward dipping beds, at various angles to the horizontal. Sets of these beds are bounded by more prominent internal reflectors. In certain areas, the reflectors are contorted, with small scale depressions within the succession that are repeated conformably throughout (Fig. 3). This unit is interpreted as seaward prograding sediments of bayhead deltas developed in response to fluctuating sediment supply and rising sea level.

Unit $3 a$ is a distinctive sub-unit that occurs in small,valleyfills within unit 3 . The valleys are up to $8 \mathrm{~m}$ deep and are preferentially developed adjacent to Unit 2 . The valley fills comprise lensoid sediment units within which small scale high angle cross bedding. The unit is interpreted as distributary channels on the delta top.

Unit 3 is truncated by surface 3 , a gently undulating subplanar surface that is interpreted as the result of wave ravinement.

Unit 4 is draped on surface 3 . It forms a fairly uniformly thick unit with strong lateral facies variability. An acoustically transparent facies up to $8 \mathrm{~m}$ thick occurs in the more offshore sections of the seismic profiles. In shallow sections this unit contains abundant subhorizontal internal reflectors (Fig. 3). These are interpreted as the distal and proximal portions of the Holocene lagoonal sediment, respectively. Jet probe cores (Fig. 2) in this unit recorded uniform fine sand and silts in distal locations and alternating gravels and coarse to very fine sands in the proximal.

\section{Discussion \& Conclusion}

A pre-existing land surface comprising juxtaposed granite (Unit 1) and Quaternary sediments (Unit 2) was flooded during the Holocene Transgression as the North Bay was formed. This likely took place quite late in the Holocene given the elevation of bedrock outcrops. The seismic profiles from the most landward section of the Bay are dominated by the presence of Unit 3, interpreted as a prograding bayhead delta of the Tres Henrique River with subordinate distributary channels (Unit 3a). This deltaic phase was terminated by wave ravinement of the upper delta surface and the onset of lagoonal sedimentation (unit 4), indicating a period of sea-level rise and bayhead delta backstepping.

No direct age constraints are avalable, but by comparison with the south Brazil sea level curve (Corrêa, 1996; Ângulo \& Lessa, 1997) and work in the adjacent Tijucas Bay (Cooper et al., submitted.), deposition can be tentatively linked to late Holocene sea-level history. The North Bay was flooded some time around 9000 yrs BP. This was accompanied by deposition of a bayhead delta offshore of the Tres Henriques River. Rapid sea level rise (possibly associated with the $8.2 \mathrm{ka}$ event and continuing to the mid-Holocene highstand of $5 \mathrm{ka}$ BP) caused bayhead delta backstepping and the onset of lagoonal sedimentation on top of the former delta surface. The contemporary lagoonal sediments record both distal and proximal facies that develop in response to distance from contemporary river sources.

The bayhead delta geometry and internal structure is similar to that reported from the Texas continental shelf (Siringan \& Anderson, 1993; Anderson et al., 1996; 
Rodriguez et al., 2010). There, bayhead deltas in incised valleys were preserved during transgression and are now preserved on the continental sheld where they are overlain by various barrier-island-related units. In Florianopolis Bay, the absence of migrating barriers in the distant section of the bay mean that the bayhead delta units are instead overlain by lagoonal sediments, while the locus of fluvial sedimentation has shifted landwards in response to transgression.

The absence of contemporary bayhead deltas is attributed to the lack of accommodation space, which has been filled by lagoonal sediments and further reduced by th fall in sea level from the late Holocene highstand.

\section{Acknowledgements}

Thanks to Conselho Nacional de Desenvolvivento Científico e Tecnológico ( $\mathrm{CNPq}$ ) for funding this project, processes (grant: 400542/2013-7), (313777/2013-6); (303550/2012-0); (400542/2013-7); and Ciência Sem Fronteira Program. UNIVALI and CB\&I for seismic data.

\section{References}

Anderson et al. (04 co-authors), 1996. Late Quaternary sedimentation and high-resolution sequence stratigraphy of the east Texas shelf. In: De Batist \& Jacobs. (eds). Geology of Siliciclastic Shelf Seas. Geological Society Special Publication, 117: 95-124.

Ângulo, R. J. \& Lessa, G. C., 1997. The Brazilian sealevel curves: a critical review with emphasis on the curves from the Paranaguá and Cananéia regions. Marine Geology. 140: 141-166.

Bhattacharya, J. P. \& Giosan, L., 2003. Wave-influenced deltas: geomorphological implications for facies reconstruction. Sedimentology, 50: 187-210.
Bonetti et al. (03 co-authors). 1998. Caracterização do Relevo Submerso da Baía Norte - SC Com Base na Aplicação Digital de um Modelo de Térreo, In: GEOSUL, Il Simpósio Nacional de Geomorfologia, Florianópolis, 27(14): 211-217.

Campos, A. V., 2011. Caracterização morfológica e sedimentar do substrato das baías norte e sul (SC) com base em técnicas de análise espacial. UFSC. Dissertação, 95p.

Corrêa, I. C. S.,1996. Les variations du niveau de la mer durant les derniers 17.500 Ans BP: I'Exemple de la PlateForme Continentale du Rio Grande do Sul- Brésil. Marine Geology, 130(1): 163-178.

Cooper et al. (07 co-authors). Sandy barrier overstepping and preservation under rapid sea level rise: an example from southern Brazil. Submetido.

Hein et al (05 co-authors), 2015. Wave energy, sediment supply, and sea-level fall: late Holocene basin infilling in Southern Brazil. Coastal Sediments 2015: Proceedings of Coastal Sediments. 1-16.

Penland, S. \& Kulp, M. A., 2005. Deltas. In: Schwartz, M.A. (ed.) Encyclopedia of Coastal Science, Kluwer, 362368.

Rodriguez, A. B., Simms, A. R. \& Anderson, J. B., 2010. Bay-head deltas across the northern Gulf of Mexico back step in response to the 8.2 ka cooling event. Quaternary Science Reviews, 29: 3983-3993.

Siringan, F. P. \& Anderson, J. B., 1993. Seismic facies, architecture, and evolution of the bolivar roads tidal inlet/delta complex, east Texas gulf coast. Journal of Sedimentary Petrology, 63(5): 794-808. 


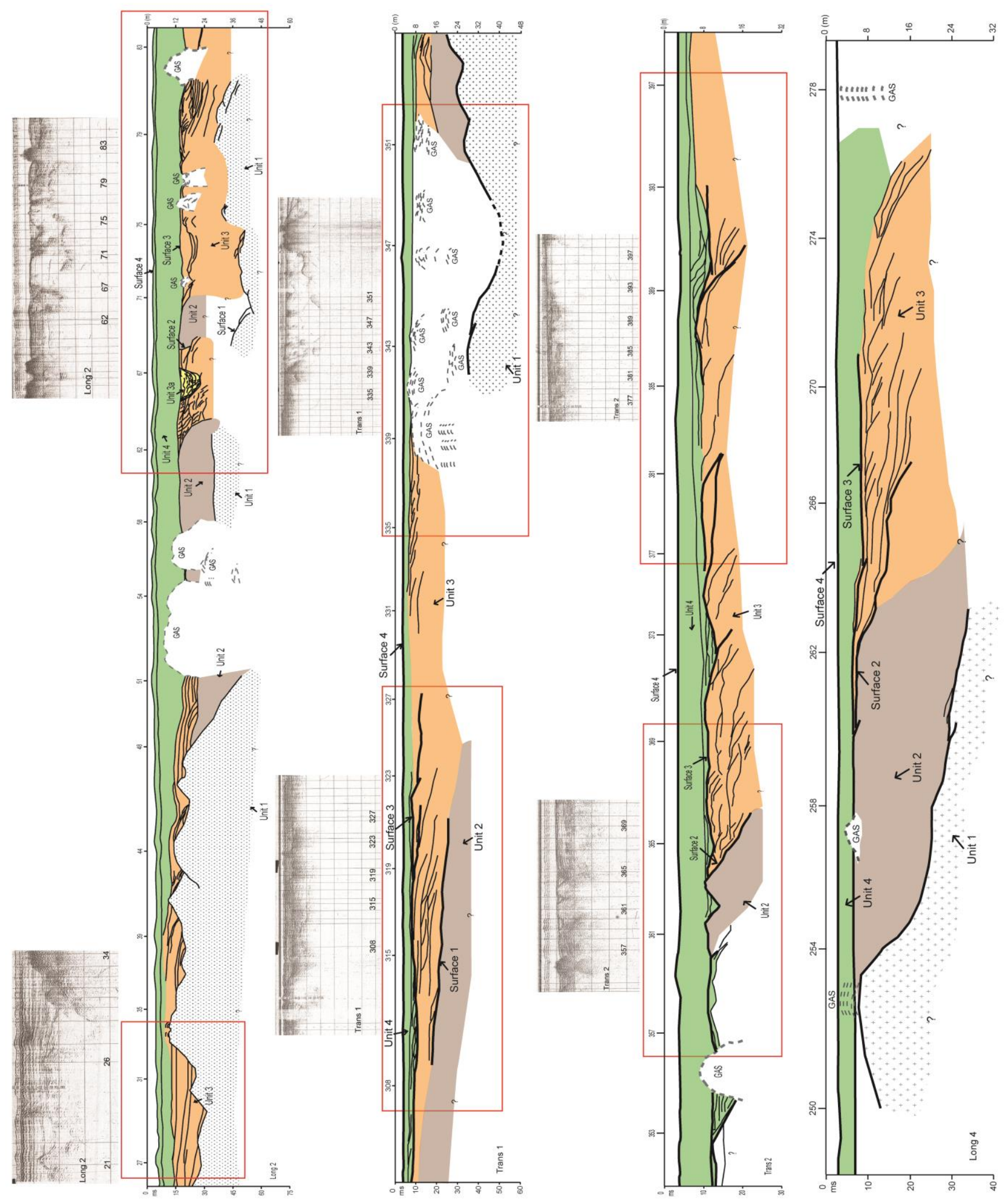

Figure 3 - High resolution BOOMER seismic profile and interpretative overlays detailing the main units and unconformity surfaces for the Florianópolis North Bay. Note the presence of four distinct seismic units (1-4) and Gas, separated by unconformity Surfaces 1 to 4. 